\title{
STUDY ON THE EFFECT OF USE OF LUXURY BRAND DURING THE SOCIAL IDENTITY PROJECTION OF INDIVIDUALS
}

\author{
Selen BUTGEL TUNALI \\ İstanbul Kültür University, Turkey \\ s.tunali@iku.edu.tr
}

\begin{abstract}
The "Social Identity Theory", which has been developed by Henri Tajfel \& John Turner, is defined as "the part of personality perception of individual, which is created with an individual's membership a group, knowledge with this membership, paid attention and emotional commitment on this membership". Social identity theory, beyond private and personal identities, touches upon the identity of a specific group membership. According to the researches about this issue, individuals reflect their social identities in the society with the products that they consumed and with the brands that they used. In this study, social identity and social identity theory is evaluated by defining the concept of identity firstly. After that, the definition of brand and the brand identity with the definition of luxury and luxury brand is made; in the end, the effect of use of luxury brand during the social identity projection of individuals is touched upon.
\end{abstract}

Keywords: Brand, social identity, luxury brand

\section{LÜKS MARKA KULLANIMININ BİREYLERİN SOSYAL KIMLIKKLERINI YANSITMADAKI ETKISİ ÜZERİNE INCELEME}

ÖZ

Henri Tajfel ve John Turner tarafından geliştirilmiş olan Sosyal Kimlik Kuramı "Kişinin benlik algısının, bir sosyal gruba ya da topluluğa üyeliği ile oluşan bilgi birikimi, bu üyeliğe verdiği değer ve duygusal bağlılıkla oluşan parçası" şekline tanımlanmaktadır. Sosyal kimlik kuramı, kişiye özel bireysel kimliklerden ziyade, onların belli bir grup üyeliği çerçevesindeki kimliği üzerinde durmaktadır. Yapılan araştırmalara göre, bireyler sosyal kimliklerini, tükettikleri ürünler ve kullandıkları markalar aracılığı ile toplum içinde sosyal kimliklerini yansıtmaktadırlar. Bu çalışmada, öncelikle kimlik tanımı yapılarak, sosyal kimlik ve sosyal kimlik kuramı anlatılmaktadır. Sonrasında ise marka tanımı ve marka kimliği ile lüks ve lüks marka tanımlanarak, lüks marka kullanımının bireylerin sosyal kimliklerini yansıtmadaki etkisi üzerinde durulmaktadır.

Anahtar Kelimeler: Marka, sosyal kimlik, lüks marka

\section{Definition of Identity}

Total of an individual's specialties with the character and the essence of a human, which is a social entity, define the "identity". According to Berger \& Luckmann (1999), identity is a phenomenon, which comes out from the interaction between the individual and society. Identity covers whole the specialties of individual. In this scope, there individual's own ideas for himself/herself and the ideas of society on individual. Individual suits the social order by his/her identity (Aşkın, 2007).

\section{Social Identity and Theory of Social Identity}

Firstly, it is a need to define the difference between the identity and the personal identity to define the social identity. Individuals communicates with the others by their own decisions, 
attitudes and personal identities, which are defined as subjective (Brown, 1988). If it is thought that people are a part of a social group, for example being a woman, being a football player, being a university student, being a mother or being a husband creates the social identities (Brehm \& Kassin, 1995). Social identity is defined as "the knowledge for an individual about paying an emotional attention on being a part of social group" (Tajfel, 1978). Explained fact here, the definition of individual that who he/she is and the value of that definition for individual.

According to the social identity theory, while individual create their own individualities, there is certainly a social group or an organization. According to this connections, the social identities are created (Lam, Ahearne, Hu \& Schillewaert, 2010). According to the social identity theory, which is defined as "the piece of a person's individuality perception which is created with knowledge that it is created by individual's membership to a social group or community, attributed value to that group or community by individual and emotional commitment" (Tajfel, 1982), the individuals, who define themselves as a member of a reference group and want to be in the society with their group identities, have are similarities in group and differences from the other groups (Korostelina, 2007). Briefly, according to the social identity theory, the social identities of individuals are created and given shaped due to the groups that individuals belong. For Berger \& Kellner (1994), "each individual wants the society to confirm continuously his/her world, which covers individual's social identity and position". That is why, individual defines himself/herself by acting compatible with his/her social identities and by considering the social group that he/she belongs. According to these definitions, individuals create their own social identities due to the groups, which are identical with their personality (Turner, 1999).

\section{Brand \& Brand Identity}

According to the American Marketing Union's definition, the brand is "name, term, sign, symbol, design, figure or the combination of all of these, which works to decide, to define, to differentiate and to distinguish the products of a specific product or a specific group of sellers" (Hisrich \& Peters, 1991). In this frame, the brand may be evaluated as a concept, which makes sense, gives spirit and promises something to customer. Brand character is the provision of brand image's emotional side. Total of consumers' experiences, which are related to brand, are effective during the creation process of brand character (Rajagopal, 2005). Brand character gains importance when it was used as a research tool to define the personal meaning of brand for customers (Aaker \& Fournier, 1995). Brand character is formulated with various methods and tools; this process needs an effective communication activity for company. In the current period, brand character has become one of the prior marketing elements, which is especially important for international companies, because of its potential to create a competition advantage. While the numbers of brands increase, in particular, the differentiation efforts of managers gets harder in the context of functionality. Then, the concept of character and its effect of consumers are always a central problematic for consumer researches (Plummer, 1985). Brand character becomes the only specialty to differentiate in the categories that the products were not differentiated too much. Accordingly, the decision-making of consumers makes the brand character an important factor to create brand value (Aaker, 1972).

At the same time, brand character is a marketing tool to develop a brand value for long term and to increase the current level of value (Supphellen \& Gronhaug, 2003). The characteristic specialties of a brand of a product or a company must be decided by enterprise. In this process, there are various ways of creating of a brand character.

One of them is the effort of matching the brand character with characters of consumers or the characters that the consumers liked (Temporal, 2000: 2):

- Determining the target group,

- Determining wishes and needs,

- Creating the profile of consumer character,

- Creating a product character, which is compatible with consumer character. 


\begin{abstract}
"Brand are used as a source, which reflects the vision that an individual wanted to be. Created symbolic meanings are transferred to brands by creating identities and they work for creating a personality for consumer and this personality's continuity as symbolic sources" (Odabaşı, 1999). Created brand characters try to be identified with individuals' social identities and the brand choices of individuals become in harmony with individuals' social identities. The symbolic sources in brand identity are seen as tools to reflect the social identity of individual.

In the thesis research of Kuşakçığlu (2003), there are also similar results. Brand defines more than a label of name; it also typifies an identity and an indicator. Some brands encode the same indicators to their user with the charisma and the quality in their identity. There is an emphasis between brand's consumer and brand by creating functional, emotional and meaningful values. To assign this relationship, it is states that the brands had to have an identity such as people had. Creating the brand identity is the most important step after creating a brand. According to "the model of brand identity planning", which was developed by Aaker (1996), after analysis for consumer, rival and brand of a brand, analyzes must be evaluated and the brand identity must be created by investigating the expectation, tendency, wish and cultural specialties consumers. Creating the brand identity is a process and a successful brand identity will be effective during decision-making process of consumers for a brand.
\end{abstract}

Aaker decided the main five dimensions of brand character and created theoretical framework of brand character (Nilsson, 1999). The brand character scale, which depends on 42 valid specialty, worked for configuring and measuring the five brand dimensions. There is consistency between the dimensions of brand characters for the consumers, who belong to different cultures. Each one of five brand characters were separated to 15 groups. 42 character specialties were collected in 15 different groups and they were created from 309 different character specialty by Aaker. The scale may be generalized for different product categories and this provides opportunity for researchers for a comparison between the general symbolic use of brand and its use for a specific product group. There five main dimensions of brand character. These are;

- Sincerity,

- Enthusiasm,

- Mastery,

- Exclusiveness,

- Hardness.

\title{
The Importance of Brand during the Creation Process of Social Identity
}

Individuals do not consistent to their social group's identity by showing compatible behaviors with that social group or by adopting the domestic ideas of that group; beside they also create their social identity by consubstantiating themselves with some brands, which reflect and consolidating their personality. They may associate their identities with these kinds of brands (Ventura, 2012). In this context, individuals have the most important tool to define themselves with these brands and with the consumption of these brands' products and services (Bhattacharya \& Sen, 2003). According to Bagozzi \& Dholakia (2006), the social identity, which was created with the use of brand by individual, increases the level of acceptance and attendance in group. It is possible for individual to differentiate himself/herself from the other groups by consuming some brands and groups; at the same time, it is possible for individual to crystallize his/her group identity (Kim, Han \& Park, 2001). Individuals or consumers show their own identity and social identities by the brands that they consumed (Fournier, 1998). The external indicators such as the products or the brands that individual used, are the most important tools to show the personality and the identity of group that individual belonged to. The theory of social identity investigates the importance of brands with used and consumed products on the motivations of individuals, their form of self-expression and their self-reliance (Bhattacharya \& Sen, 2003). Brands make possible to communicate between brand and consumers with brand characters that they created; beside, brands also make possible for 
individuals to show their social group with the external indicators. Thus, consumers make a powerful communication with brands to create their own identities by using the created identities of brands (Fournier, 1998). There is a powerful relationship between individuals' consumption materials and creations process of their social and personal identities; because, when the issue was investigated the consumption behaviors of individuals, it is seen that the benefits of products to create an identity for individual are more important their quality, performance and structure (Atwal \& Williams, 2009). The product, which is used by individual, is bought because of its semiotic value more than functional benefit. Individual lives an identification between him/her and product or brand by the indicator, which is created by the symbolic meaning of a product or a brand.

Because brands are the richest sources for individuals to define themselves and to reflect their social identities, individuals want to complete their identity with brands. There is a deep symbolism behind the brand and each symbol is the greatest assistant of individuals to reflect the social identity (Albert, Merunka, \& Valette-Florence, 2008).

Because of these reasons, when the relationship between individuals and the products, brands that they used, the level of importance of the relationship between "Theory of Social Identity" and brand choice increases day by day. In the current period, because of the excess of different choices in the same product category, the brands try to create an identity just like individuals and search for the possibilities to make connection with individuals; because the reason that people chose the products and brands is related to their identities such as benefits, performance and specialties. When the identities and the meanings that they reflected investigated the concepts of "luxury" and "luxury brands"; because luxury brands are not consumed because of their concrete benefits, their symbolic meanings and identities are the basic reasons for consumers to prefer these luxury brands (Dikmen, 2008).

In the light of this information, firstly, the role of luxury brands to explain the social identities of individuals will be touched upon by stating the concept of luxury and luxury brand identity to understand the relationship between social identity and brand well.

\section{The Concepts of Luxury and Luxury Brand}

In the modern world, while the consumers are encouraged for consumption, individuals, in accordance of unlimited product choices, make their decisions with the abstract values such as the identity and image of products and services. Beyond the functional values that brands presented, social and symbolic values of brands have become quite important during the decision-making process of individuals on products (Altuna \& Arslan, 2016). The word of luxury comes from the word of "luxe" in French. The word of "lux", which means "light" in Latin language and it is used for different meanings. According to that, the users of luxury brands are the individuals, who shine and make themselves different from the rest of society (Catry, 2003). For Heilman, Kaefer, \& Ramenofsky, (2007), the concept of luxury is used to emphasize the social classes of individuals by giving the feelings of happiness and satisfaction to individuals.

In marketing, the luxury brand is defined as product or service groups, which address to highincome class and is high-priced, high quality and has high social image (Yeoman \& Beattie, 2006). The luxury brands must have the unique place in consumers' minds, have a unique identity and reflect this to the consumer, who preferred that brand (The Brand Age). When the products, which are used by individuals that they belonged to A SES group, were evaluated, Rolex watch, Gucci bag, Versace suit, Ferrari and Aston Martin cars, Sunset Restaurant for food and Four Seasons Hotel to roost are the first brands, which come to mind. The social values that the brands had, are in the foreground to prefer those brands (Sweeney \& Soutar, 2001). Besides the feeling of pleasure, which is presented by brands that they pay attention satisfaction and 
taste as emotional value, is in the foreground. Social value has motive of reflecting the tastes, which are suitable for individual's social environment. Right in this point, choices of luxury brands gain importance to reflect the social status of individuals as an indicator of status and it is evaluated as a factor, which makes the individuals privileged. Social and behavioral psychologists states that external and internal factors must be utilized to explain the concept of luxury besides social and emotional benefit (Çiftyıldız \& Sütütemiz, 2011). The ideas, confirms and suggestions of people, who are in the individual's social environment, create the basis of external factors; senses and feelings, which force the individual to prefer luxury products create the basis of internal factors. In this context, luxury products are products, which provides reputation and status to individual and found rarely. They also include the internal factor with the pleasure that everybody cannot reach those products.

\section{The Effect of Use of Luxury Brand during the Social Identity Projection of Individuals}

Luxury brands need unique brand identity to have a peerless status in their customers mind (Altuna \& Arslan, 2016). That is why the effect of luxury brands to project the social identities of individuals with their privileged identity is so important. Individuals' luxury brand usage and the urge to reflect their social identity in the social environment to which they belong with the use of luxury brand emphasized in psychology-based researches (Nelissen \& Meijers, 2011; Dreze \& Nunez, 2009). Kadığlu (2013) examined the social identity theory and consumer behaviors and consumption phenomenon. In the groups that individuals wanted to belong, social identity gives them a social confirmation with their consumption styles. Individuals' consumption preferences reflect their identity. Every brand the individuals that have used, even the house or vacation preferences can be seen as the reflection of their social identities. Individuals especially use luxury brands to position themselves based on the social identity.

The use of luxury brand provides the consumer psychological benefits rather than providing a physiological benefit (Şaylan, 2014). Based on the sociological research, causes that motivate luxury consumption are listed. Some of these are:

- "Showing off

- Showing richness

- Expressing the lifestyle

- Being an Avant-Garde (Pioneer)

- Increasing the prestige

- Highlighting the social status

- Showing the difference from the other categorizes of the" (Şaylan, 2014) It has been underlined that as an individual we need brands to reflect the social environment that we belong to and reflect that social identity. Luxury brands are created 'rare' positioning at this stage also positions the user with the same ID. Thus the individual without introducing itself, when in a social environment with the brand choices choose the easiest path, so luxury brand consumption has been increasing in recent years.

For this reason brands that are used as a symbol are listed:

1. Louis Vuitton

2. Rolex

3. Cartier

4. Gucci

5. Burberry

6. Hermès

7. Chanel

8. Prada

9. Tiffany

10. Armani (Chadha \& Husband, 2006). 
Gucci noticed the importance of creating "Premium" brand identity in 1950s within the framework of a marketing plan created a brand identity. Gucci as an Italian luxury brand, to reflect its social identity as the preferred brand made its positioning with European Royal Family and Hollywood celebrities (Jackson \& Haird, 2003). The creation of Gucci social identity is the reflection of a successful marketing communication and the reflection of the brand identity. This reflection has started in 1921 in Florence with the name of The House of Gucci; today the world- famous art works are side by side with the Gucci Museum (Gucci Museo) (Yanık, 2014). What makes luxury brands different and the reason behind using these brands as a reflection of the social identity is the value that they have been giving to the symbolism. The symbols like Louis Vuitton's monogram, Rolex's crown, Cartier's panther and Gucci's double ' $G$ ' are identities that reflects the brand in the social environment (Yanık, 2014; Kapferer, 2010). The role of the designer on this identity creation cannot be underestimated. With Tom Ford's step into the creative process Gucci has gained its present brand identity and continues to exist as a brand that reflects unchanging social identity. (Moore \& Fernie, 2004) In a focus group research for luxury brand usage a participant explains using a luxury brand like this: "Using a Gucci bag gives me a privileged image, the monogram is known from everyone and in this way people who knows that I have paid 850 dollars for this bag have an idea about my social identity. So for me using Gucci is a physical spell" (Venkatesh \& the others, 2010). In the research, one of the most important reasons of using a luxury brand is its contribution of the identity creation.

Moore \& Fernie who have examined the development of Burberry as a luxury brand (2004), taking over as a subject of research the strategy of conversion to a luxury brand from the brand that appeals to middle English economy class with a new brand identity in 1997. Marketing communication is examined clear and simple sense of design, correct distribution strategy and brand new, young, elite identity as a part of the luxury brand positioning. It has gained the English elite brand identity emphasis with its stores, commercials and with its changing logo. Like in the Gucci example, individuals prefer these brands to create the positioning between the identities that the brands have created and their own identities (Fletcher, 2003). In another research, Gucci and Old Navy brands have been examined (Kim and Sung, 2013). In the conducted research, even if they have similar advertisement scenarios based on their different brand identities one of them addresses to the middle and low class and the other one addresses to different category as a result of luxury brand positioning. This luxury brand positioning is presented in a clear manner to the recipients with the fashion shows and famous people or with the successful installations into the movies. Burberry consolidates its brand positioning with the fashion shows twice a year, which are held in London, Milan and New York (Moore and Birthwistle, 2004). In the same way, Victoria's Secret made its own brand positioning with the highly anticipated fashion shows. Manolo Blahnik the luxury shoe brand created an identity with the main character of Sex and The City 'Carrie Bradshaw' (Yeoman \& Beattie, 2006). The character underlined a pair of shoes contribution to the social identity almost every episode and emphasized that who wears these shoes in real life are part of an elite group.

As a result of the global luxury research brand it has been emergent that each year 80 billion dollars has been spent on this. \%37 of these expenditures have been done in Far East countries in these countries with\%62 Japan has the highest expenditure (JP Morgan, 2005). Researchers are examined the luxury brand usage in Far East countries as a result of the increasing connection between using a luxury brand and creating a social identity. It has been emphasized that, in Tokyo A and B socio-economic levels of women at \%94 and the remaining percentage of women at economic levels in $20 \%$ have own Louis Vuitton handbags (Chadha and Husband, 2006). In the same research it has been said that, someone who lives in the Far East uses Louis Vuitton bag, Armani suit and Rolex watch to reflect the social identity that he/she belongs. In this way, without any effort and saying anything individuals are underlining the importance of 
using luxury brands as a way to reflect their own identity. "Luxury brands are modern symbol sets for Asian people to describe their identities and social status (Chadha \& Husband, 2006).

In today's world not only for Asians but also for all people selected brands are symbol for them to show their social status in the society.

\section{Conclusion}

Briefly, it has been observed that the social group the individual belongs has an important role in determining the individual's thoughts and behaviors. According to the social identity theory social identities are formed and shaped depending on the groups that the individual belongs. According to this social identity, it has been observed that individuals use brands to position themselves in the community to which they belong and reflect themselves to the members of the groups, which they belong. Just as individuals brands has an identity and this identity is also formed through certain stages of creation. Accordingly, if there is a harmony and balance between the brand identity and individual's social identity, individuals use these brands to reflect their identities.

It can be seen that symbols and specific social identity determiners have attributed great value and these are taken root as a social value; these meaning units are shared subjectively. The brand symbolism is gaining a social value because luxury brand exists within the culture as a general point. When luxury brand symbolism is successful, consumers have them in their interaction with each other, belonging formations and uses them as socialization elements and status markers; these symbols of life becomes a natural part of the whole social tissue. Even though most of the brands have not official brand community, symbolically socially strong brands are symbolic source for the consumers at the point of continuing their lives.

\section{References}

Aaker, David A., (1996), Building Strong Brands. New York : The Free Press

Aaker, Jennifer Lynn, Susan Fournier, (1995), A Brand as a Character, A Partner and a Person: ThreePerspectives on the Question of Brand Personality, Advances in Consumer Research, Vol.22, pp.391-395.

Albert, N., Merunka, D., \& Valette-Florence, P. (2008). When consumers love their brands: Exploring the concept and its dimensions. Journal of Business research, 61(10), 1062-1075.

Aşkın, M. (2007). Kimlik ve giydirilmiş kimlikler. Atatürk Üniversitesi Sosyal Bilimler Enstitüsü Dergisi, 10(2).

Atwal, G., \& Williams, A. (2009). Luxury brand marketing-the experience is everything!. Journal of Brand Management, 16(5), 338-346.

Altuna O. K. ve Arslan M., (2016). Ayna ayna söyle bana var $m ı$ benden daha lüks marka? The Brand Age ( Erişim Tarihi: 22 Şubat 2016)

Berger, P., \& Kellner, H. (1994). Marriage and the construction of reality: An exercise in the microsociology of knowledge. The psychosocial interior of the family

Berger, P. and Luckmann, T., (1999). "Socialization: The Internalization of Society" Meaninig of Sociology, 6th. Edition. Printice Hall.

Bhattacharya, C. B., \& Sen, S. (2003). Consumer-company identification: A framework for understanding consumers' relationships with companies. Journal of marketing, 67(2), 76-88.

Brehm, S. ve Kassin, S. M. (1993). Social Psychology. Boston: Houghton Mifflin Company.

Brown, R. (1988). Group processes: Dynamics within and betıueen groups. Oxford: Basil Blackvvell Inc. Demirtaş H. A.: (2003). Sosyal Kimlik Kuramı, Temel Kavram ve Varsayımlar. Iletişim Araştırmaları Dergisi, 1(1), 123- 144.

Catry, B. (2003). The great pretenders: the magic of luxury goods. Business Strategy Review, 14(3), 10-17.

Chadha, R., \& Husband, P. (2010). Cult of the luxury brand: inside Asia's love affair with luxury. Nicholas Brealey Publishing. 
Çiftyildiz, Saim Saner ve Sütütemiz,Nihal (2007), “Tüketici İlgisinin Marka Bağlılığına Etkisi”, Kocaeli Üniversitesi Sosyal Bilimler Enstitüsü Dergisi, 13(1), ss. 37-55.

Dikmen, G. Ö. (2008). Lüks Marka Pazarlamas1, "Vertu” Örneği. İletişim Fakültesi Dergisi, 31, 51-64.

Dreze, X., \& Nunez, J. C. (2009). Feeling superior: The impact of loyalty program structure on consumers' perceptions of status. Journal of Consumer Research, 35, 890-905.

Fletcher, R. (2003), "Brava, bravo!", The Sunday Telegraph,5 October.

Fournier, S. (1998). Consumers and their brands: Developing relationship theory in consumer research. Journal of consumer research, 24(4), 343-353.

Heilman, C., Kaefer, F., \& Ramenofsky, S. (2007). Luxury Good Expenditures of Husband and Wife Dyads Incorporating User Attitudes. Advances In Consumer Research, 34, 410.

Hisrich, R.D. and Peters, M.P. (1995) Entrepreneurship: Starting, Developing, and Managing a New Enterprise. 3rd ed. Chicago: Irwin.

Kadıŏlu Z.K., (2013) Kitle İletişim Araçlarının Şekillendirdiği Sosyal Kimlikler ve Aidiyet Duygusu Ekseninde Tüketici Davranışları, İstanbul Üniversitesi İletişim Fakülte Dergisi

Kim, C. K., Han, D., \& Park, S. B. (2001). The effect of brand personality and brand identification on brand loyalty: Applying the theory of social identification. Japanese Psychological Research, 43(4), 195-206.

Kim, D. H., \& Sung, Y. (2013). Gucci versus Old Navy: Interplay of brand personality and regulatory focus in advertising persuasion. Psychology \& Marketing, 30(12), 1076-1087.

Korostelina, K. (2007). The system of social identities in Tajikistan: Early warning and conflict prevention. Communist and Post-Communist Studies, 40(2), 223-238.

Kuşakçıŏlu, A. (2003). Marka Kimliği, Kurum Kimliği ve Aralarındaki Bağıntı. Yüksek Lisans Tezi, Ankara Üniversitesi,Sosyal Bilimler Enstitüsü.

Lam, S. K., Ahearne, M., Hu, Y., \& Schillewaert, N. (2010). Resistance to brand switching when a radically new brand is introduced: A social identity theory perspective. Journal of Marketing

Moore, C. M., \& Fernie, J. (2004). Retailing within an international context. International retail marketing: A case study approach, 3-37.

Moore, C. M., \& Birtwistle, G. (2004). The Burberry business model: creating an international luxury fashion brand. International Journal of Retail \& Distribution Management, 32(8), 412422.

Nelissen, R. M., \& Meijers, M. H. (2011). Social benefits of luxury brands as costly signals of wealth and status. Evolution and Human Behavior, 32(5), 343-355.

Nilsson, Kent, Susanne Bonde, (1999), Consumer Perception of Brand Personality A Quantitative Approach, Bachelor's Thesis Lulea Tekniska Universitet.

Plummer, Joseph T, (1985), How Personality Makes a Difference, Journal of Advertising Research, Vol. 24, No: 6, pp.27-31.

Rajagopal, (2005), Impact of Advertising Variability on Building Customer Based Brand Personality under Competitive Environment: Empirical analysis in reference to Mexico, Latin American Business Review, Vol.6(3), pp.63-84.

Tajfel, H. (1978). "The achievement of group differentiation." Dijferentiation betıveen social groups: Studies in the social psychology ofintergroup relations. (Der.) H. Tajfel. London: Academic Press. 77-101Supphellen, Magne, Kjell Gronhaug, (2003), Building foreign brand personalities in Russia: the moderating effect of consumer ethnocentrism, International Journal of Advertising, Vol. 22, Iss.2, pp.203-226.

Sweeney, J. C., \& Soutar, G. N. (2001). Consumer perceived value: The development of a multiple item scale. Journal of retailing, 77(2), 203-220.

Şaylan M. (2014) Lüks Marka Yönetimi ve Lüks Ürün Pazarlamas1, http://muratsaylan.blogspot.com.tr/ (Erişim Tarihi: 1 Kasım 2014)

Tajfel, H. (1982) "Social Psychology of Intergroup Relations", Annual Review of Psychology, $33,1-39$. 
Tajfel, H. ve Turner J.C. (1985) "The Social Identity Theory of Intergroup Behavior". The Psychology of Intergroup Relations içinde Der: Worchel, S.ve Austin, W.G.2, 7-24, Chicago: Nelson Hall.

Temporal, P. (2000), Branding in Asia, John Wiley \& Sons, Singapore, pp. 11, 25-6, 33.

Turner, C. John. (1999). Some current issues in research on social identity and selfcategorization theories. In N. Ellemers, R. Spears ve B. Doosje (Eds.), Social iden- tity (pp.634). Oxford, England: Blackwell Publishers.

Venkatesh, G., Sampson, J., Goulding, N., Garcia, S., Bryksin, V., Lugo-Martinez, J., ... \& Taylor, M. B. (2010, March). Conservation cores: reducing the energy of mature computations. In ACM SIGARCH Computer Architecture News (Vol. 38, No. 1, pp. 205-218).

Ventura, K. (2012). Sanal Marka Topluluklarında Topluluk Üyelerinin Marka ile Özdeşleşme Düzeylerinin Öncülleri ve Sonuçları: Yapısal Bir Model Önerisi. Yönetim ve Ekonomi: Celal Bayar Üniversitesi İktisadi ve İdari Bilimler Fakültesi Dergisi, 19(2), 197-217.

Yanık O. (2014), Türkiye'den Gucci çıkar mı? http://thebrandage.com/turkiyeden-gucci-cikarmi/ (Erişim Tarihi: 26 Aralık 2014)

Yeoman, I., \& McMahon-Beattie, U. (2006). Luxury markets and premium pricing. Journal of Revenue and Pricing Management, 4(4), 319-328. 